NASA/TM-1999-209380

\title{
A Solar Dynamic Power Option for Space Solar Power
}

Lee S. Mason

Glenn Research Center, Cleveland, Ohio

Prepared for the

34th Intersociety Energy Conversion Engineering Conference sponsored by the Society of Automotive Engineers

Vancouver, British Columbia, Canada, August 1-5, 1999

National Aeronautics and

Space Administration

Glenn Research Center 
Available from

NASA Center for Aerospace Information

7121 Standard Drive

National Technical Information Service 5285 Port Royal Road Springfield, VA 22100

Hanover, MD 21076

Price Code: A03

Price Code: A03 


\title{
A Solar Dynamic Power Option for Space Solar Power
}

\author{
Lee S. Mason \\ National Aeronautics and Space Administration \\ Glenn Research Center \\ Cleveland, Ohio 44135
}

\begin{abstract}
A study was performed to determine the potential performance and related technology requirements of Solar Dynamic power systems for a Space Solar Power satellite. Space Solar Power is a concept where solar energy is collected in orbit and beamed to Earth receiving stations to supplement terrestrial electric power service. Solar Dynamic systems offer the benefits of high solar-to-electric efficiency, long life with minimal performance degradation, and high power scalability. System analyses indicate that with moderate component development, SD systems can exhibit excellent mass and deployed area characteristics. Using the analyses as a guide, a technology roadmap was generated which identifies the component advances necessary to make SD power generation a competitive option for the SSP mission.
\end{abstract}

\section{INTRODUCTION}

The Space Solar Power (SSP) concept represents an attempt to provide environmentally benign, terrestrial electric power with positive economic rate-of-return. In order to satisfy these goals, the solar power generation system must 1) provide very high power levels to the beam power source to maximize delivered power to Earth, 2) be very lightweight to control launch costs, and 3 ) be extremely long-lived to minimize maintenance and upkeep requirements. One representative SSP configuration has a power generation requirement of 1.6 Gigawatts (GW), a power system specific power goal of $1000 \mathrm{~W} / \mathrm{kg}$, and system lifetimes of 20 years [1]. This representative configuration would be located in medium Earth orbit (approximately $12000 \mathrm{~km}$ ), although options in geosynchronous Earth orbit are also being considered. The representative system would deliver $400 \mathrm{MW}$ to the Earth receiving station.

Power system options for SSP include photovoltaic (PV) arrays and Solar Dynamic (SD) power systems. A wide range of $\mathrm{PV}$ cell technologies are being considered including thin-film blankets and multi-junction crystalline cells. SD heat engine technology options include
Brayton, Stirling, and Rankine. This study assumes the use of closed Brayton cycle (CBC) conversion based on its potential for high power and its relative technical maturity. Figure 1 shows a potential layout for a SSP SD power module utilizing a refractive fresnel concentrator and Brayton conversion.

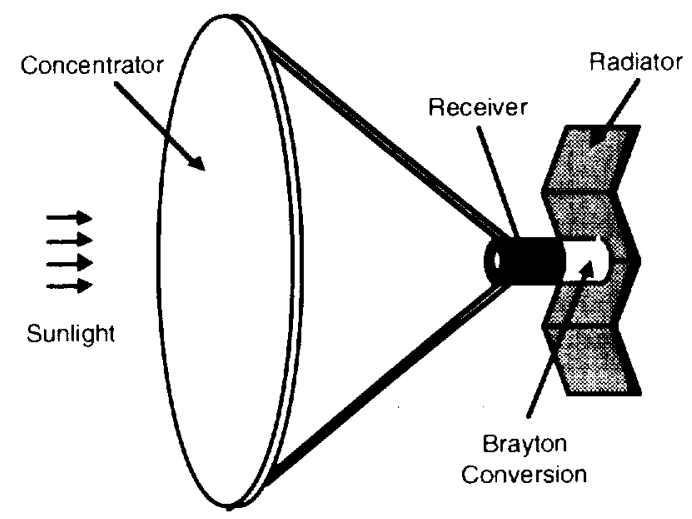

Figure 1. SD Power Module Layout

\section{SOLAR DYNAMIC OPERATING PRINCIPLES}

Solar Dynamic power systems concentrate sunlight into a receiver where the energy is transferred to a heat engine for conversion to electrical power. Brayton heat engines utilize a turbine, compressor, and rotary alternator to produce power using an inert gas working fluid. A schematic diagram of the CBC system is shown in Figure 1. The heated fluid from the receiver is expanded through a turbine, cooled through a heat exchanger where waste heat is transferred to a liquid coolant, and pressurized in a compressor before being re-heated by the solar receiver. A recuperative heat exchanger between the turbine discharge and receiver inlet is often used to improve cycle efficiency. Waste heat transferred to the liquid coolant, is dissipated via radiator panels to space. The rotary alternator typically provides three phase, alternating current (ac) at about 1 $\mathrm{khz}$ to the power management and distribution (PMAD) for electrical conversion (if needed) and distribution to the spacecraft bus. 


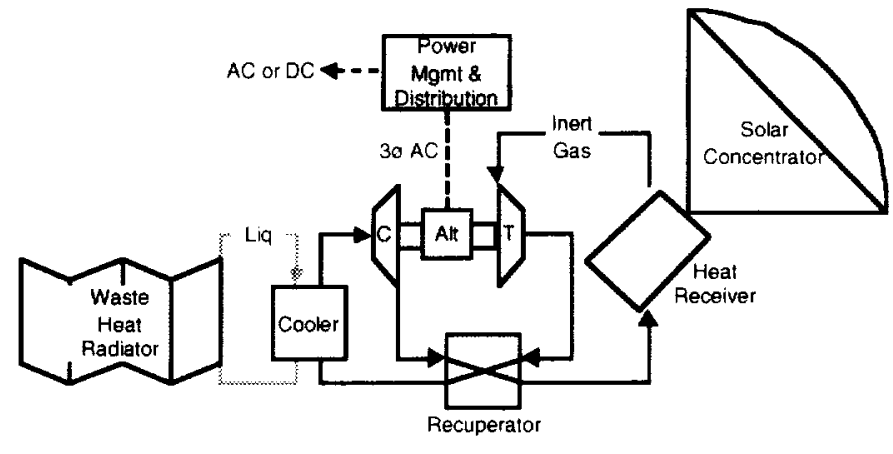

Figure 2. Brayton Cycle Schematic

\section{SYSTEM CONCEPT}

The SSP requirements represent a considerable challenge for any space power system. Today's space power systems provide at most, 10's of kilowatts with system specific power levels of about $10 \mathrm{~W} / \mathrm{kg}$ and lifetimes of 5 to 10 years. Solar Dynamic systems have the potential to surpass these metrics by taking advantage of the benefits of non-linear power scalability offered in turbo-machinery and heat exchangers. Of course, the power levels required for SSP are a considerable extension of the current state-of-the-art in SD space power technology.

The challenges of satisfying SSP power levels with very high specific power and long life can best be met through a disciplined SD development effort consisting of two principal phases: 1) near term, component evolution, and 2) farther term, technology infusion. The specific technology advances associated with these phases are described later in this paper.

The $1.6 \mathrm{GW}$ power generation requirement will likely be satisfied through a modular power system approach. A single power system module would be limited in mass to the maximum payload capability of the launch vehicle. This avoids the complexity of intra-system assembly onorbit and allows the overall power system to be assembled in a plug-in and operate mode. A reasonable size for an SSP SD power module, based on projected launch vehicle capabilities ( $<20$ tonnes) and solar concentrator size expectations $(<200 \mathrm{~m}$ diameter) is about $10 \mathrm{MW}$. Table 1 shows the projected system-level performance benefits that could be achieved. For a 10 MW SD power module, it is estimated that system specific power can be improved from about $20 \mathrm{~W} / \mathrm{kg}$ with today's technology, to nearly $120 \mathrm{~W} / \mathrm{kg}$ with near term component evolution, to over $700 \mathrm{~W} / \mathrm{kg}$ with far term technology.

A total of $160,10 \mathrm{MW}$ SD modules would be needed to satisfy the $1.6 \mathrm{GW}$ SSP power requirement. The resulting SSP satellite could have 40 modules along the length and 4 modules across the width in a staggered configuration. This configuration is similar to the "Power
Tower" approach being considered for PV power generation. The 14.1 tonne SD modules would connect to a main power distribution backbone that would feed the beam supply antenna. The overall SSP power generation system would have an areal footprint of 9.5 $\mathrm{km}$ by $0.65 \mathrm{~km}$ and a total system mass of 2256 tonnes.

\section{Table 1. Performance Projections for a 10 MW SD Module}

\begin{tabular}{|l|c|c|c|}
\hline & $\begin{array}{c}\text { State-of-the- } \\
\text { Art }\end{array}$ & Near Term & Far Term \\
\hline $\begin{array}{l}\text { System Specific } \\
\text { Power, W/kg }\end{array}$ & 21 & 116 & 709 \\
\hline $\begin{array}{l}\text { System Specific } \\
\text { Area, W/m }\end{array}$ & 283 & 389 & 450 \\
\hline $\begin{array}{l}\text { Brayton Cycte } \\
\text { Efficiency }\end{array}$ & $38.8 \%$ & $41.8 \%$ & $47.1 \%$ \\
\hline $\begin{array}{l}\text { Solar-to-Electric } \\
\text { Efficiency }\end{array}$ & $29.4 \%$ & $32.7 \%$ & $35.1 \%$ \\
\hline $\begin{array}{l}\text { Concentrator } \\
\text { Area, m }\end{array}$ & 24799 & 22285 & 20767 \\
\hline $\begin{array}{l}\text { Concentrator } \\
\text { Diameter, m }\end{array}$ & 178 & 168 & 163 \\
\hline $\begin{array}{l}\text { Radiator Area, } \\
m^{2}\end{array}$ & 10135 & 3195 & 1394 \\
\hline
\end{tabular}

\section{SYSTEM BENEFITS}

SD technology offers several significant benefits for the SSP application including:

- Low solar collection area

- High voltage, ac power generation

- Existing high power infrastructure

- Suitability to mass production

- Long life components

- Inherent radiation tolerance

Recent testing of a $2 \mathrm{~kW}$ SD power system, described later in this paper, demonstrated cycle efficiencies of almost 30\% using 1970's and 1980's component technology. Significant improvements in efficiency can be realized with newer technology and properly selected design parameters including the Brayton cycle temperature ratio (Tratio) and compressor pressure ratio (CPR). The high efficiency directly translates into reduced solar collection area and a smaller satellite areal footprint. Smaller modules also ease launch vehicle packaging and orbital deployment requirements.

SD technology offers the distinct advantage of ac power generation which could provide considerable transmission cable weight savings at SSP power levels as compared to direct current (dc) distribution. Further, the rotary alternator of the Brayton unit can be custom 
wound to provide very high voltages, perhaps as high as $10,000 \mathrm{Vac}$. The high voltage at the source helps to reduce resistive losses, and improve the overall power system efficiency.

High power, Brayton cycle technology is utilized in many terrestrial applications. Gas turbine electric power plants can provide 100's of megawatts and are in widespread use in North America and Europe. Aircraft auxiliary power units, that provide 100's of kilowatts, are found in most of today's larger commercial jets. Gas turbine systems are also prevalent in marine propulsion applications. This infrastructure provides a basis for mass production of SSP SD power units, particularly the turbo-machinery components and heat exchangers. Mass production will be key to controlling the recurring costs for SSP power systems.

Long life is made possible through the use of noncontacting gas foil bearings, hermetic sealing of the gas circuit, redundant electronic components, and ultraviolet/atomic oxygen protective coatings on all optical surfaces. Radiation degradation is reduced relative to solar photovoltaic arrays since semiconducting materials are not used on the large exposed surfaces. Long life power systems are essential to assure cost feasibility of the SSP concept.

\section{TECHNOLOGY ROADMAP}

Solar Dynamic and space Brayton technology has been under development for over 30 years. In the 1960's, several $10 \mathrm{~kW}$ Brayton Rotating Units (BRU) were designed, developed and tested [2]. The BRU family of units successfully achieved over 40,000 hours of test operation. Following BRU in the mid-1970's, a $1.3 \mathrm{~kW}$ unit known as mini-BRU was designed and developed for isotope power applications [3]. Much of the development experience from the BRU units went into the design of a $25 \mathrm{~kW}$ SD module for Space Station Freedom during the 1980's. Under the Freedom program, detailed designs for the solar concentrator, heat receiver and radiator were completed [4]. A fullscale solar concentrator was also completed. Unfortunately, the Freedom SD development ended prematurely due to Space Station funding limitations.

\section{SOLAR DYNAMIC GROUND TEST DEMONSTRATION}

A subscale development of the Freedom SD module was proposed as a fully integrated system ground test in a simulated space environment. The $2 \mathrm{~kW}$ SD Ground Test Demonstration (GTD), shown in Figure 3, was completed at the NASA Glenn Research Center. The test included an off-axis solar concentrator, heat receiver with thermal energy storage (TES), recuperated-Brayton cycle heat engine, and waste heat radiator in a thermal vacuum environment. The TES, a LiF-CaF2 phase change material contained in canisters surrounding the gas flow tubes, was used to heat the working fluid during the eclipse to allow continuous power production through the orbit, eliminating the need for secondary batteries. The Brayton engine was assembled using the mini-BRU hardware fabricated in the 1970's. The testing was conducted with a solar simulator to provide a complete solar-to-electrical system demonstration. Cycle efficiencies (ratio of alternator power to heat input) of the Brayton unit were measured at $29 \%$ and orbital efficiencies (ratio of electrical energy output to solar energy collected over an orbit) were measured at $17 \%$. From 1994 to 1998 , the system had accumulated nearly 800 hours of operation including 33 ambient start-ups and 372 orbit cycles [5].

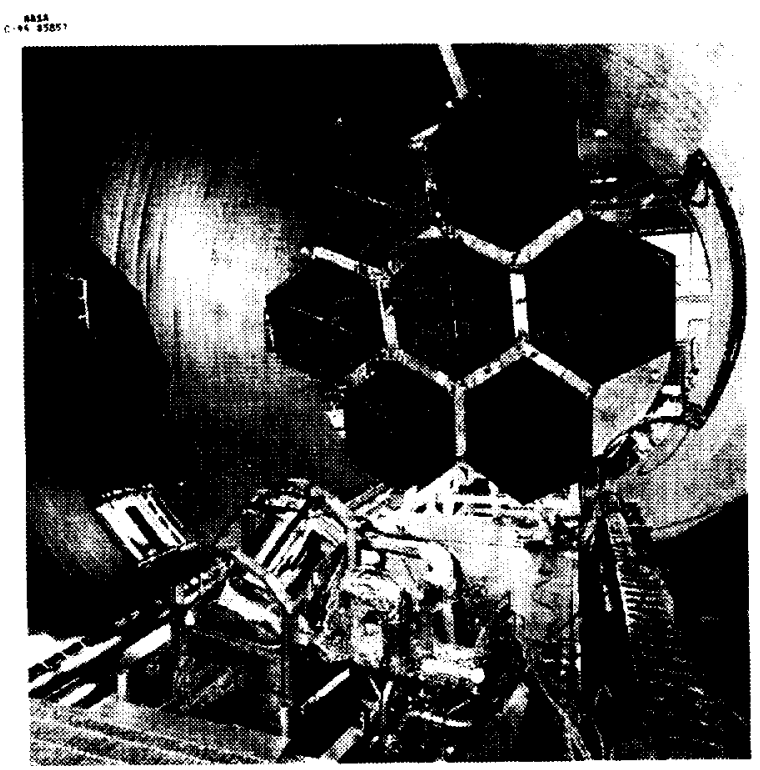

Figure 3. SD Ground Test Demonstration at NASA Glenn Research Center

A flight version of the $2 \mathrm{~kW}$ system, which utilized a similar receiver and Brayton cycle engine to the ground test system and a Russian designed concentrator and radiator, was planned for 1998 but was cancelled due to Shuttle manifest changes. A significant portion of the flight receiver, engine, and controls were completed prior to the project's cancellation and some of the flight development hardware was integrated with the GTD testbed for performance characterization.

\section{COMPONENT TECHNOLOGY ADVANCEMENT}

The system ground testing demonstrated the efficiency potential of SD power, but not the mass potential needed for SSP. The system was comprised of component technologies from earlier programs, not optimized for mass. Advanced component development is necessary to achieve a mass competitive space power system for SSP. Table 2 describes the component advances associated with a two phase development discussed previously. It should be noted that many of these 
technology advances including lightweight structures, advanced materials, and high voltage/high temperature electronics are applicable to any SSP power system development.

Table 2. SD Component Advances

\begin{tabular}{|c|c|c|c|}
\hline & State-of-the-Art & Near Term & Far Term \\
\hline $\begin{array}{l}\text { Concen- } \\
\text { trator }\end{array}$ & $\begin{array}{c}\text { Rigid Panels, } \\
\text { Al Coating, } \\
86 \% \text { EOL } \\
\text { Reflectance, } \\
10 \mathrm{~kg} / \mathrm{m}^{2}\end{array}$ & $\begin{array}{c}\text { SRP, } \\
\text { Ag Coating, } \\
92 \% \text { EOL, } \\
2 \mathrm{~kg} / \mathrm{m}^{2}\end{array}$ & $\begin{array}{c}\text { Rigidized } \\
\text { Inflatable, } \\
\text { Ag Coating, } \\
92 \% \mathrm{EOL} \\
0.2 \mathrm{~kg} / \mathrm{m}^{2}\end{array}$ \\
\hline Receiver & $\begin{array}{l}\text { Gas Tube/ } \\
\text { Canister, } \\
\text { Superalloys, } \\
\mathbf{1 . 5} \mathrm{kg} / \mathrm{kW}\end{array}$ & $\begin{array}{l}\text { Na Heat Pipes, } \\
\text { Refractory } \\
\text { Alloys, } \\
0.12 \mathrm{~kg} / \mathrm{kW}_{\mathrm{t}} \\
\end{array}$ & $\begin{array}{l}\text { Li Heat Pipes, } \\
\text { High Temp } \\
\text { Graphite, } \\
0.12 \mathrm{~kg} / \mathrm{kW}\end{array}$ \\
\hline $\begin{array}{l}\text { Brayton } \\
\text { Conv. } \\
\text { ersion }\end{array}$ & $\begin{array}{c}\text { Superalloy Hot- } \\
\text { End, } 1100 \mathrm{O} \\
\text { Turbine Inlet, } \\
3.5 \text { Tratio, } \\
2.2 \text { CPR, } \\
92 \% \text { Turbine, } \\
85 \% \text { Comp, } \\
95 \% \text { Recup, } \\
95 \% \text { Alternator, } \\
0.2 \mathrm{~kg}^{\prime} \mathrm{kW}_{e} \\
\end{array}$ & $\begin{array}{c}\text { Refractory Hot- } \\
\text { End, } 1500 \mathrm{~K} \\
\text { Turbine Inlet, } \\
3.8 \text { Tratio, } \\
2.3 \text { CPR, } \\
92 \% \text { Turbine, } \\
85 \% \text { Comp, } \\
95 \% \text { Recup, } \\
95 \% \text { Alternator, } \\
0.2 \mathrm{~kg} / \mathrm{kW}_{\theta}\end{array}$ & $\begin{array}{c}\text { Ceramic Hot- } \\
\text { End, } 2000 \mathrm{~K} \\
\text { Turbine Inlet, } \\
4.5 \text { Tratio, } \\
2.6 \text { CPR, } \\
92 \% \text { Turbine, } \\
85 \% \text { Comp, } \\
95 \% \text { Recup, } \\
95 \% \text { Alternator, } \\
0.2 \mathrm{~kg} / \mathrm{kW}_{\mathrm{e}}\end{array}$ \\
\hline Radiator & $\begin{array}{l}\text { SS Tubes, } \\
\text { Al Honeycomb } \\
\text { Panels, } \\
\text { Pumped Loop, } \\
\text { n-Heptane, } \\
12 \mathrm{~kg} / \mathrm{m}^{2} \\
\end{array}$ & $\begin{array}{c}\text { Al Tubes, } \\
\text { C-C Panels, } \\
\text { Pumped Loop, } \\
\text { NaK, } \\
6 \mathrm{~kg} / \mathrm{m}^{2}\end{array}$ & $\begin{array}{c}\text { Graphite Tubes, } \\
\text { Inflatable } \\
\text { Panels, } \\
\text { Pumped Loop, } \\
\text { NaK, } \\
1.5 \mathrm{~kg} / \mathrm{m}^{2} \\
\end{array}$ \\
\hline PMAD & $\begin{array}{c}500 \mathrm{~V}, 1 \mathrm{kHz}, \\
30 \text { Alt; } 60^{\circ} \mathrm{C} \mathrm{Si} \\
\text { Electronics, } \\
10 \mathrm{kV} \text { Dist, } \\
100 \mathrm{~m} \text { Cable, } \\
95 \% \text { Eff, } \\
1.9 \mathrm{~kg} / \mathrm{kW}_{\odot}\end{array}$ & $\begin{array}{c}5 \mathrm{kV}, 1 \mathrm{kHz}, 3 \varnothing \\
\text { Alt; } 150^{\circ} \mathrm{C} \mathrm{SiC} \\
\text { Electronics, } \\
10 \mathrm{kV} \text { Dist, } \\
100 \mathrm{~m} \text { Cabie, } \\
93 \% \mathrm{Eff}, \\
1.0 \mathrm{~kg} / \mathrm{kW}_{0} \\
\end{array}$ & $\begin{array}{c}10 \mathrm{kV}, 1 \mathrm{kHz}, \\
30 \mathrm{Alt} ; 300^{\circ} \mathrm{C} \\
\text { SiC Electronics, } \\
10 \mathrm{kV} \text { Dist, } \\
100 \mathrm{~m} \text { Cable, } \\
93 \% \mathrm{Eff} \\
0.2 \mathrm{~kg} / \mathrm{kW}_{\mathrm{\theta}}\end{array}$ \\
\hline
\end{tabular}

\section{Near Term Technology}

The elements of a near term SD component development effort would include 1) a lightweight, deployable solar concentrator, 2) a sodium heat pipe, heat receiver, 3) a refractory alloy, Brayton conversion unit, and 4) a lightweight, composite material radiator. A spline radial panel (SRP) solar concentrator would reduce the areal density of the SD collector by a factor of five from $10 \mathrm{~kg} / \mathrm{m}^{2}$ for conventional rigid panel concentrators to less than $2 \mathrm{~kg} / \mathrm{m}^{2}$. SRP concentrators, based strongly on advanced radio-frequency antenna technology, also provide reduced stowage volume and autonomous deployment. This near term concentrator will also improve the end-of-life (EOL) reflectance from $85 \%$ to $92 \%$ with the use of silver coatings. A heat pipe receiver (without TES) would reduce the specific mass of the SD heat receiver by more than $10 X$ from $1.5 \mathrm{~kg} / \mathrm{kW}$, for conventional gas tube receivers to about $0.1 \mathrm{~kg} / \mathrm{kW}_{1}$. Heat pipe receivers also allow higher cavity flux levels, and greater flux variation easing the pointing and surface accuracy requirements of the concentrator. The higher temperature, refractory Brayton would permit an increase in the turbine inlet temperature resulting in nearly $70 \%$ savings in radiator area. A composite radiator, using carbon-carbon (C-C) structural materials, reduces the areal density of the SD heat rejection system by a factor of two from $12 \mathrm{~kg} / \mathrm{m}^{2}$ for conventional aluminum panels to only $6 \mathrm{~kg} / \mathrm{m}^{2}$.

\section{Far Term Technology}

The next phase of technology development would need to be more revolutionary focusing on ultra-light weight inflatable structures and high temperature materials. The main elements of the program would include 1) a rigidized, inflatable concentrator, 2) a high temperature graphite receiver, 3) a ceramic Brayton engine, and 4) an inflatable, graphite tube radiator. The inflatable concentrator is expected to provide a $10 \mathrm{X}$ reduction in areal density over the SRP system from 2 to $0.2 \mathrm{~kg} / \mathrm{m}^{2}$ while assuring long life through rigidization. The high temperature graphite receiver, with lithium heat pipes, combined with the ceramic Brayton engine would permit turbine inlet temperatures at $2000 \mathrm{~K}$. The high temperature hot-end allows the engine to operate at a large temperature ratio and yet maintain a relatively high heat rejection temperature. These attributes provide the potential for very high cycle efficiency $(>45 \%)$ and significant reductions in concentrator area $(7 \%)$ and radiator area $(56 \%)$ relative to the near term, advanced component system. An inflatable waste heat radiator at $1.5 \mathrm{~kg} / \mathrm{m}^{2}$ would offer more than a factor of three improvement in areal density over the $\mathrm{C}-\mathrm{C}$ radiator.

\section{Power Management and Distribution}

A focussed PMAD development effort must accompany the SD component advances. The progression from state-of-the-art to near term, to far term technology includes the development of a high voltage alternator, high temperature electronics, and high power switchgear. The SD electrical power converter is expected to include only transformers and filters to boost the alternator voltage from 100's Vac to 1000's Vac. As shown in Table 2, the PMAD system specific mass, assumed to include the converter, radiator, and a $100 \mathrm{~m}$ transmission cable would vary from $1.9 \mathrm{~kg} / \mathrm{kW}$ to 0.2 $\mathrm{kg} / \mathrm{kW}$ depending on the alternator voltage, electronics temperature, and the areal density of the PMAD radiator.

\section{DEVELOPMENT PLAN}

A preliminary development schedule for the overall SD technology roadmap is presented in Figure 4. Initial efforts would focus on component design studies, and fundamental materials and coatings evaluation. The ensuing component development phase would address both SD specific technologies and dual purpose technologies applicable to any SSP power system. Considerable emphasis would be placed on developing high power components. An early subscale, integrated system flight test is a key milestone leading to the ultimate full-scale system demo in the 2016 to 2020 timeframe. 


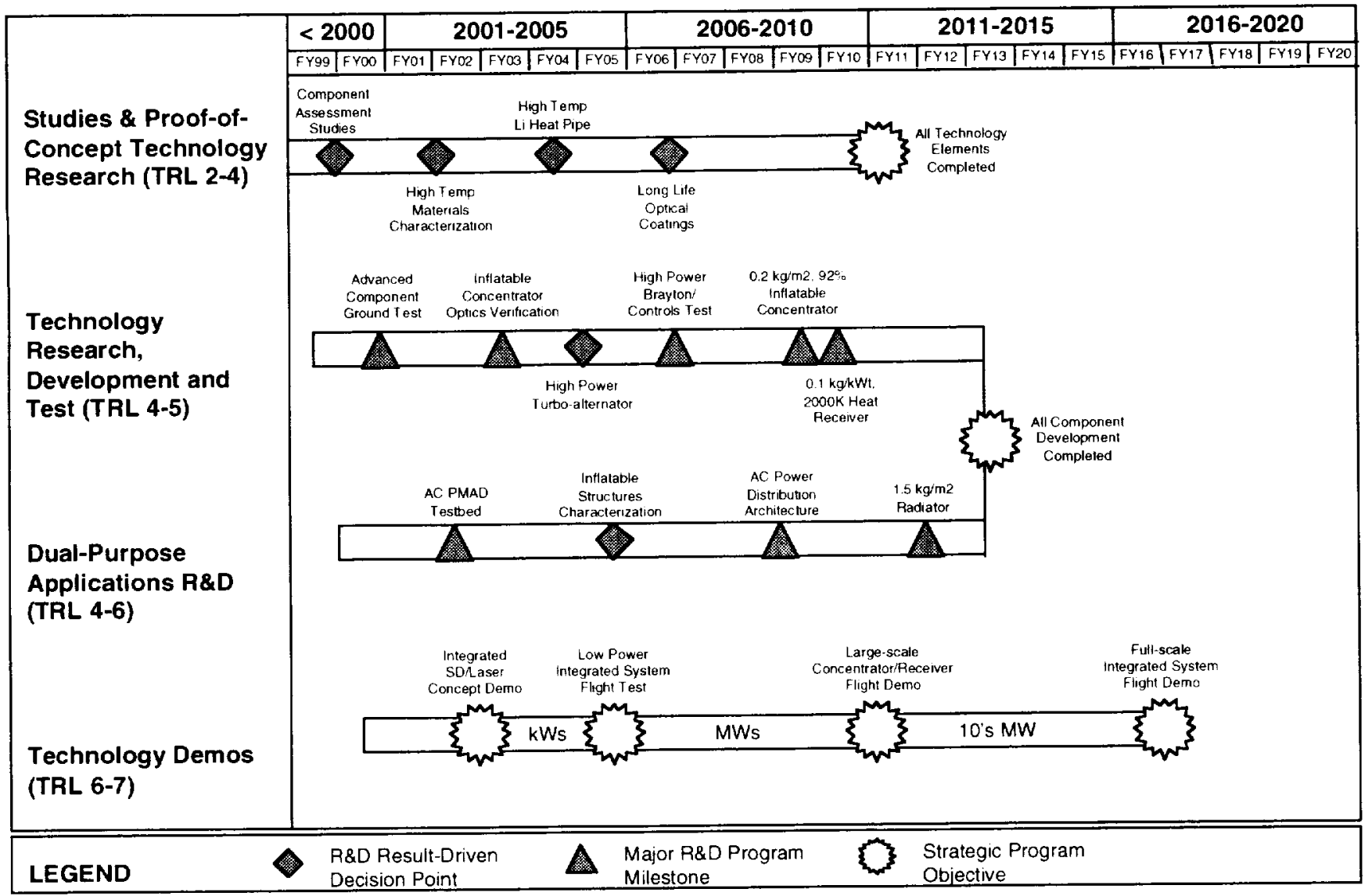

Figure 4. Technology Development Plan

\section{CONCLUSION}

The results of this study indicate that SD power generation technology could offer SSP a viable alternative to more conventional solar photovoltaic systems. SD systems provide many attractive benefits including high efficiency, long life, and high power scalability. By following a regimented component development plan, SD systems can also provide low mass and deployed area. The component advances discussed in this paper can be realized with reasonable initial costs. The early studies and proof-of-concept development work would provide the foundation for a more informed assessment of the performance projections described here.

\section{CONTACT}

Lee Mason is a senior power system engineer in the Power and On-Board Propulsion Technology Division at Glenn Research Center. He can be contacted by phone at (216) 977-7106 or through e-mail at Lee.Mason@grc.nasa.gov.

\section{References}

[1] Parker, J., Feingold, H., "Space Solar Power System Functional Mission Concept and Architecture (FMC\&A)," Marshall Space Flight Center, August 5, 1998.

[2] Davis, J.E., "Design and Fabrication of the Brayton Rotating Unit," NASA CR-1870, 1972.

[3] Dobler, F.X., "Mini-BRU/BIPS 1300 Watt Dynamic Power Conversion System Development," NASA CR-159440, 1978.

[4] Jefferies, K.S., Ed., "Solar Dynamic Power System Development for Space Station Freedom," NASA RP1310, 1993.

[5] Shaltens, R.S., and Mason, L.S., "800 Hours of Operational Experience from a $2 \mathrm{~kW}_{\mathrm{e}}$ Solar Dynamic System," NASA TM-1999-208840, 1999. 
Public reporting burden for this collection of information is estimated to average 1 hour per response, including the time for reviewing instructions, searching existing data sources, gathering and maintaining the data needed, and completing and reviewing the collection of information. Send comments regarding this burden estimate or any ather aspect of this collection of information, including suggestions for reducing this burden, to Washington Headguarlers Services, Directorate for Intormation Operations and Davis Highway, Suite 1204. Artington, VA 22202-4302, and to the Office of Management and Budget. Paperwork Reduction Project (0704-0188), Washington, DC 20503.

\begin{tabular}{|l|c|c|}
\hline 1. AGENCY USE ONLY (Leave blank) & $\begin{array}{c}\text { 2. REPORT DATE } \\
\text { July } 1999\end{array}$ & $\begin{array}{r}\text { 3. REPORT TYPE AND DATES COVERED } \\
\text { Technical Memorandum }\end{array}$ \\
\hline
\end{tabular}

\section{TITLE AND SUBTITLE}

A Solar Dynamic Power Option for Space Solar Power

\section{FUNDING NUMBERS}

\section{AUTHOR(S)}

Lee S. Mason

\section{PERFORMING ORGANIZATION NAME(S) AND ADDRESS(ES)}

National Aeronautics and Space Administration

John H. Glenn Research Center at Lewis Field

Cleveland, Ohio 44135-3191

WU $-6.32-81-0 \mathrm{~A}-00$

9. SPONSORING/MONITORING AGENCY NAME(S) AND ADDRESS(ES)

National Aeronautics and Space Administration

Washington, DC 20546-0001
8. PERFORMING ORGANIZATION REPORT NUMBER

E- 11803

\section{SUPPLEMENTARY NOTES}

Prepared for the 34th Intersociety Energy Conversion Engineering Conference sponsored by the Society of Automotive Engineers, Vancouver, British Columbia, Canada, August 1-5, 1999. Responsible person, Lee S. Mason, organization code 5490, (216) 977-7106.

\section{2a. DISTRIBUTION/AVAILABILITY STATEMENT}

12b. DISTRIBUTION CODE

Unclassified - Unlimited

Subject Categories: 20 and 44

Distribution: Nonstandard

This publication is available from the NASA Center for AeroSpace Information. (301) 621-0390.

\section{ABSTRACT (Maximum 200 words)}

A study was performed to determine the potential performance and related technology requirements of Solar Dynamic power systems for a Space Solar Power satellite. Space Solar Power is a concept where solar energy is collected in orbit and beamed to Earth receiving stations to supplement terrestrial electric power service. Solar Dynamic systems offer the benefits of high solar-to-electric efficiency, long life with minimal performance degradation, and high power scalability. System analyses indicate that with moderate component development. SD systems can exhibit excellent mass and deployed area characteristics. Using the analyses as a guide, a technology roadmap was generated which identifies the component advances necessary to make SD power generation a competitive option for the SSP mission.

\section{SUBJECT TERMS}

Solar dynamic power systems; Brayton cycle; Space power satellites

17. SECURITY CLASSIFICATION
OF REPORT
Unclassified

NSN 7540-01-280-5500

18. SECURITY CLASSIFICATION
OF THIS PAGE
Unclassified

19. SECURITY CLASSIFICATION
OF ABSTRACT
Unclassified

15. NUMBER OF PAGES

$$
11
$$

16. PRICE CODE

$$
\mathrm{A} 03
$$

\section{LIMITATION OF ABSTRACT}



' 